\title{
THE DEVELOPMENT OF DUSTING METHOD FOR DRAGON FRUIT PEEL AS FINGERPRINT VISUALIZATION
}

\author{
Sri Adelila Sari* and Ade Novita Sari Lubis
}

\author{
Chemistry Department, FMIPA, State University of Medan \\ J. William Iskandar Ps. V No.104, Kenangan Baru, Percut Sei Tuan, Deli Serdang, \\ Sumatera Utara 20371, Indonesia
}

*Correspondence: email: adelilaunimed@gmail.com

\begin{abstract}
Various fingerprint powder preparations used for fingerprints have a color or contrast and a sticky material for good adhesion. However, some chemical substrates used for fingerprint powders are toxic and have the potential to harm health. This research is essential to overcome this problem using a new natural powder, namely dragon fruit peel powder, as a latent fingerprint development that was simple, non-toxic, and cheaper than commercial used fingerprint powder. Fingerprint development was carried out on non-porous surfaces (aluminium foil, CD, glass preparations) and porous surfaces (HVS paper, spectra paper, paperboard). This study used 90 fingerprint samples based on ethnicity (Batak, Javanese, Malay), blood type, and gender. The development of fingerprints using dragon fruit peel powder resulted in clear visualization on the surface of aluminium foil and glass preparations with sizes of 100 and 200 mesh. Meanwhile, fingerprints on the paper surface resulted in poor visualization because the protrusions of the fingerprints were not visible. The most dominant fingerprint patterns based on ethnicity, blood group, and gender were the loop pattern, then the whorl, and the smallest arch, respectively.
\end{abstract}

Keywords: Development, dusting method, dragon fruit peel, and latent fingerprint

\section{INTRODUCTION}

A fingerprint is defined as a pattern formed by the ridges at the fingertips containing rows of pores connected to the sweat glands-unique, unchanging, universal fingerprint, easy to classify. Fingerprints from crime scenes can be used to identify suspects or victims [1]. In general, the three fingerprint traces found at a crime scene are visible (patent print), an impression (plastic mould), and latent print [2]. Therefore, it is necessary to have a material or compound that can visualize latent fingerprints so that fingerprints are visible on a surface. The material used must be adapted to the conditions or surface shape where the latent fingerprint is attached [3].

The powder technique has been used as a method since the early 1900 s. Currently, various fingerprint powder preparations used have a color or contrast and are sticky material for good adhesion. Universally, there are four methods of fingerprint powder, namely ordinary, Luminous, metallic and thermoplastic. When fingerprint powder is sprinkled on the surface where the fingerprints are present, the powder will stick to oil, sweat or other things left on the fingerprint [4]. 
Also, applying talc to latent prints gives an immediate, clear print result [5]. The police often carry out the identification process using powder because it is relatively simple, cheap and relatively easy[3]. Identification of latent fingerprints using the powder method with natural ingredients has been carried out by many researchers. It has been developed using the durian seed dust method [6]. It was also succeeded in performing fingerprint visualization on bond paper, scrap paper, wooden surfaces, plastics, transparent sheets, aluminium foil, steel surfaces and Compact Disks [7]. It has researched the visualization of latent fingerprints with the sweeping method on herbal ingredients, namely turmeric [8], gambir powder [9] and purple sweet potato powder (Ipomoea batatas $L$. Poiret) [10].

When choosing a powder composition, certainly, the material does not chemically interact with the surface of the latent fingerprint trace. The powder selected should provide the best color contrast to the surface. Some of the chemical substrates used for fingerprint powders are toxic and pose potential health hazards [11]. To overcome this, this research was conducted using a new, natural powder, namely powder from dragon fruit peel powder, as a latent fingerprint development that is simple, nontoxic, and cheaper than the fingerprint powder used commercially.

Dragon fruit (Hylocereus undatus) is a plant with high economic value and health benefits [12]. Dragon fruit peel percentage $30-35 \%$ of the fruit weight and often just disposed of as garbage [13]. One of its uses in dragon fruit peel is by extracting it to be used as a base for various functional foods that will benefit health [14]. Super red dragon fruit peel can also be used for making jelly [15]. Red dragon fruit peel is used as a food additive in making ice cream because it contains natural pigments that can be used as an alternative to synthetic dyes, thereby eliminating doubts that it will be bad for health [16]. Dragon fruit peel contains anthocyanin dyes that are quite high. In red dragon fruit peel, anthocyanin levels are $22.59 \mathrm{ppm}$. Red flesh dragon fruit peel contains anthocyanin pigment, cyanidin 3-ramnosyl glucoside 5glucoside [17].

The development of latent fingerprint dusting methods is important, and using dragon fruit peel waste as a visualization of latent fingerprints on porous surfaces (HVS paper, spectra paper, paperboard) and nonporous surfaces (glass preparations, aluminum foil, and $\mathrm{CD}$ ) becomes something new and interesting to research. This study used 90 fingerprint samples based on ethnicity (Javanese, Batak, and Malay), blood type and gender. This ethnic variation was used because it was following the population data of Medan city that the highest percentage of Medan city based on ethnicity was Batak, Javanese and Malay. This study used 90 fingerprint samples based on ethnicity (Javanese, Batak, and Malay), blood type and gender. This ethnic variation was used because, according to the population data of the city of Medan, the highest percentage of Medan cities based on ethnicity were Batak, Javanese and Malay.

The idea of using a sample based on this category was consistent with the assertion that the fingerprint pattern is one 
biological variation that differs from one racial group with other groups, between women and even men in identical twins. Each individual shows a different fingerprint pattern fingers but has a regularity that can be easily identified. The average frequency of each pattern and other characteristics shows an evident variation among the population [18]. Fingerprint can widely be used to identify a person in terms of the biology of his derivation and differences between ethnic groups [19]. The researchers' results also found variations in fingerprint patterns of various ethnic groups [8-10, 20].

Fingerprint analysis by gender and blood in the individual group has the advantage, which can increase the authenticity of fingerprints. Also, fingerprint patterns can help predict a person's gender and blood type to solve a crime. The blood group system was discovered in 1901 by Karl Landsteiner. Thus, 19 major groups were identified, which varied in their distribution among the various human races. Clinically, only very important 'ABO' and 'Rhesus' groups [21].

\section{METHODS}

\section{Tools}

The tools used were a blender, sieve (60, 80, 100 and 200 mesh), beaker glass, powder container, fingerprint brush, spatula, and tube clamp.

\section{Materials}

The materials used were $500 \mathrm{gr}$ dragon fruit peel, HVS paper, paperboard, spectra paper, CD, glass preparations, aluminum foil, $10 \mathrm{~mL}$ ethyl acetate (Sigma), and $40 \mathrm{~mL}$ petroleum ether (Sigma).

\section{Research Procedure}

\section{a. Dragon Fruit Peel Powder Preparation}

Red dragon fruit peel was sliced into small pieces. Then did the drying using an oven at a temperature of $30-380 \mathrm{C}$ [14]. Then it was blended and sieved using a 60,80 , 100 , and 200 mesh sieve. The purpose of refinement was to expand the surface of the sample particles [22].

\section{b. Fingerprint Development}

The method of developing latent fingerprints using the dusting method or nonporous surface (aluminum foil, $C D$, and glass preparations) with dragon fruit peel powder smeared by rotating the brush over the mold circular pattern so that the latent print can be seen on the object surface. The powder that did not stick to the fingerprint was immediately removed to visible the fingerprint [23].

The method of developing latent fingerprints was by dusting on porous surfaces (HVS paper, spectra paper, and paperboard), namely by dissolving $50 \mathrm{mg}$ of dragon fruit peel powder in $10 \mathrm{~mL}$ ethyl acetate, then mixed it with $40 \mathrm{~mL}$ of petroleum ether. Fingerprint samples were immersed in the solution, then aired, then in the oven for 1 hour at $150^{\circ} \mathrm{C}$ [25].

\section{RESULTS AND DISCUSSION}

\section{Dragon Fruit Peel Powder Preparation}

Red dragon fruit peel contains anthocyanins. The smaller the water content and the smaller the dragon fruit peel grain 
size, the higher the anthocyanin content [26].

Conditions free of light, low temperature, copigment, metal ions, oxygen, enzymes, concentration, and pressure are also important factors so that the stability of anthocyanins was maintained so that the balance of anthocyanins does not easily shift and eventually degrades [27]. Anthocyanins were very sensitive to thermal processes that can cause red color loss and an increase in brown color due to thermal degradation. The color degradation of anthocyanins was due to changing the red flavilium cations to carbinol bases and finally to colorless chalcone and ending in brown degradation products [28]. The resulting dragon fruit powder was brown. Dragon fruit peel powder in Figure 1.

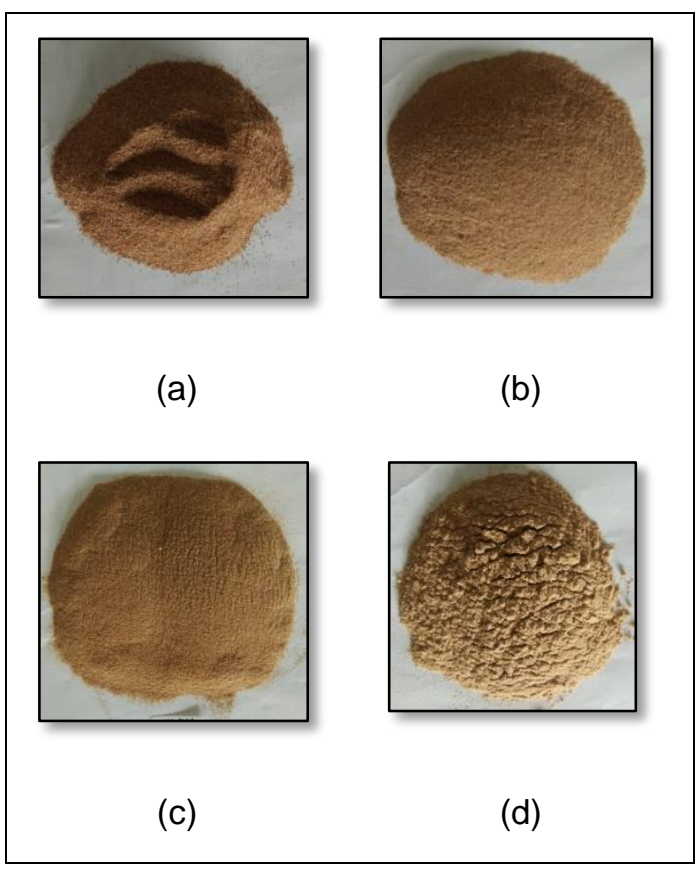

Figure 1. Powder of dragon fruit peel resulting from sieve / mesh (a) 60, (b) 80 , (c) 100 , and (d) 200

\section{Development of Dragon Fruit Peel Powder Dusting Method}

\section{a. Development of Fingerprints on Non- Porous Surfaces}

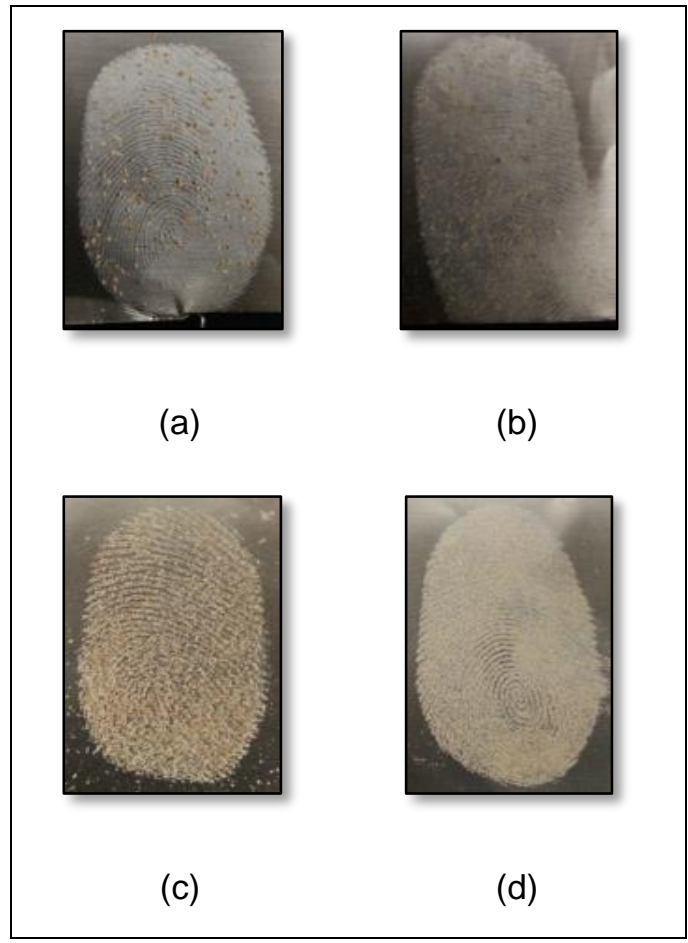

Figure 2. Development of latent fingerprints on the surface of aluminum foil with powder / mesh sizes (a) 60, (b) 80, (c) 100 , and (d) 200

The development of latent fingerprints of dragon fruit peel powder was carried out by the dusting method. The dusting method involves rubbing dragon fruit peel powder on a surface that contains sebum. To collect sebum prints, the subject was asked to touch the forehead or face to get sebum on the tips of his fingers. The powder would be sticked to the residue from the surface radius we touched [6]. The development of latent fingerprints using dragon fruit peel powder was carried out on aluminium foil, glass preparations, and CDs. Visualization of latent fingerprints on the aluminium foil, $C D$, and the glass surface of the preparation can be seen in Figure 2, 3, and 4 , respectively. 


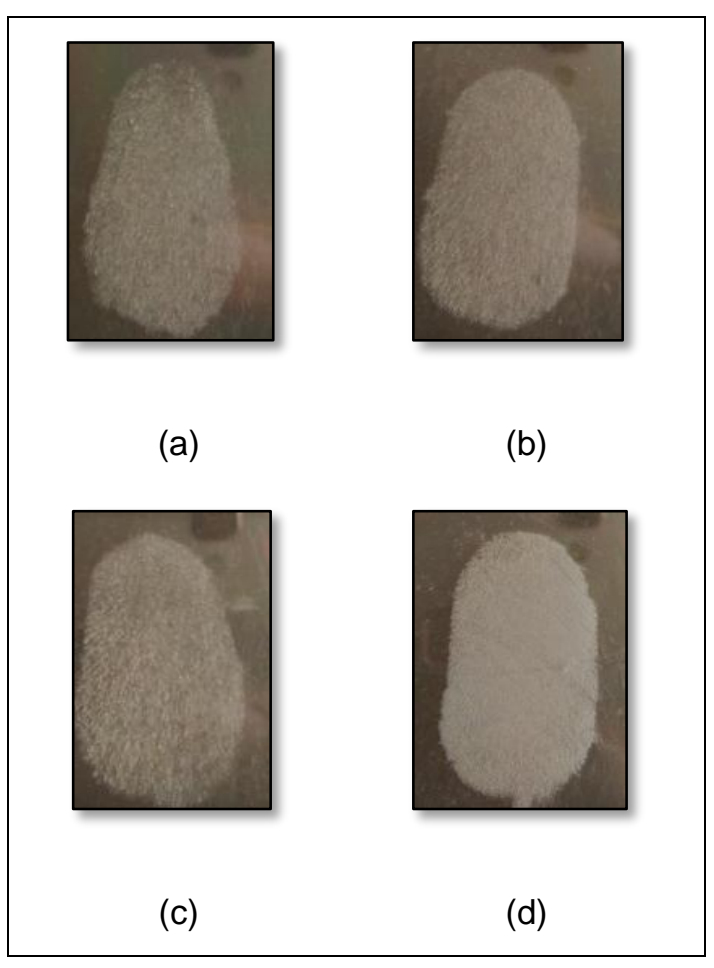

Figure 3. Development of latent fingerprints on the CD surface with powder/mesh sizes (a) 60, (b) 80, (c) 100, and (d) 200

Dragon fruit peel powder with 100 mesh and 200 mesh on the surface of aluminium foil and glass preparations gives results with clear color contrast. Meanwhile, the resulting 60 mesh and 80 mesh of the resulting visualization was not good enough. Due to the finer powder's size, it made it easier for the brush to come into contact with the surface/media, making it easier to identify the patterns/lines found on fingerprints [9].

The CD's surface makes for poor visualization of latent fingerprints because the powder cannot stick to the CD's surface. The smaller the powder particle size, the wider the surface of the material is. It might be due to the wider surface of the material, thus increasing the contact between the powder particles [29].

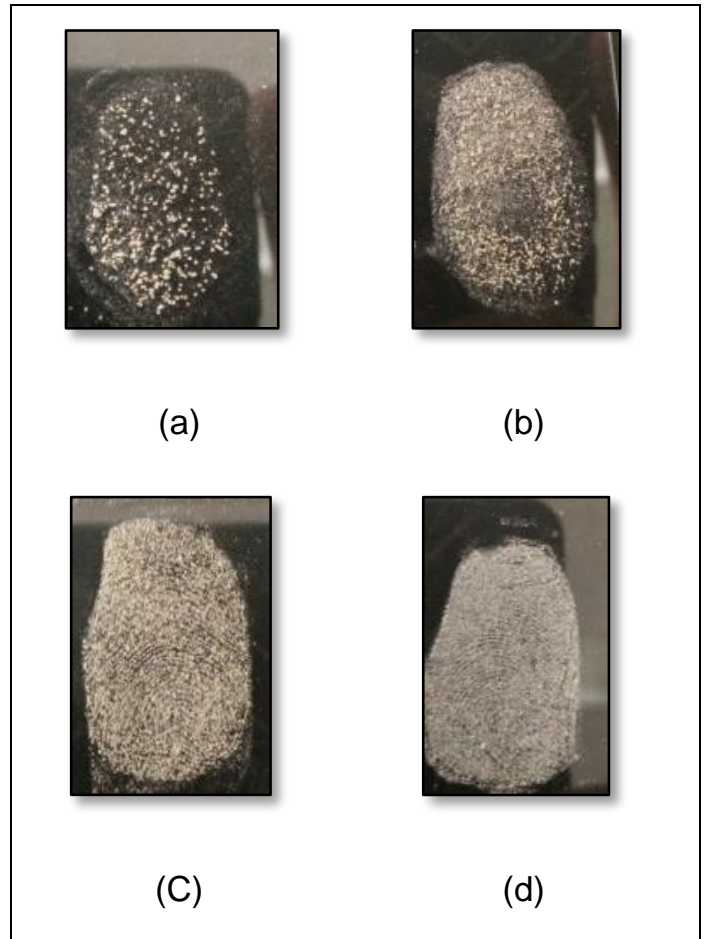

Figure 4. Development of latent fingerprints on the surface of the glass preparations with powder/mesh sizes (a) 60, (b) 80, (c) 100, and (d) 200

The development of the fingerprint with the powder was based on the adhesion of the powder to the water contained in the latent fingerprint. The powder was only used to develop latent fingerprints found on nonsweat-absorbing (non-porous) surfaces such as glass, porcelain, varnished/varnished/ painted surfaces others [30].

\section{b. Development of Fingerprints On Porous Surfaces}

The development of latent fingerprints using dragon fruit peel powder was also carried out on the paper surface. The development of latent fingerprints on the paper surface requires a reagent solution, either by immersion or spraying. The ideal reagent should be rapidly evaporated, nontoxic, non-flammable, and non-polar to avoid ink diffusion in the developed documents 
[31]. Chemical latent fingerprint development was used on the surface of objects that absorbs sweat like paper, unpainted wood cardboard. Here it could not be used or erased from the paper's surface, thus affected to the authenticity of a document [30].

The development of fingerprints on the paper's surface with $50 \mathrm{mg}$ of dragon fruit peel powder was dissolved in $10 \mathrm{ml}$ of ethyl acetate, stirred until the powder was dissolved. Then mixed with $40 \mathrm{ml}$ of petroleum ether. Fingerprint samples were immersed in the solution for a few seconds and aerated. Then the fingerprint samples were put in an oven at $1500 \mathrm{C}$ for 60 minutes [25]. Figure 5 is the reaction of cyanidine 3ramnosyl glucoside 5-glucoside in dragon fruit peels plus ethyl acetate and petroleum ether to produce 5- (- 6-Acetoxymethoxymethyl-3,4,5-trihydroxy-tetrahydro-pyran-2yloxy)-3-(2-acetoxymethoxymethyl-3,4,5trihydroxy- tetrahydro-pyran-3-yloxy) 2- (3,4bis-acetoxymethoxy-phenyl) chromenylium.

In this research, fingerprints used three types of paper, namely HVS paper, paperboard, and spectra paper. Figure 6 is a reaction 5-(-6-Acetoxymethoxymethyl-3,4,5-trihydroxy-tetrahydro-pyran-2yloxy)-3-(2-acetoxymethoxymethyl-3,4,5trihydroxy-tetrahydro-pyran-3-yloxy)2-(3,4bis-acetoxymethoxy-phenyl)-chromenylium.
In this research, the development of fingerprints uses three types of paper, namely HVS paper, paperboard, and spectra paper. Fig. 6 is a reaction 5-(-6Acetoxymethoxymethyl 3,4,5-trihydroxy-tetrahydro-pyran-2-yloxy)-3-(2-acetoxymethoxymethyl-3,4,5-tryhydroxy-tertrahydropyran3-yloxy)2-(3,4-bis-acetoxymethoxy-phenyl)chromenylium with alanin in sweat produces 5-(6-Acetoxymethoxymethyl3,4,5-trihydroxy-tetrahydro-pyran-2-yloxy)-2(3,4-bis-acetoxymethoxy-phenyl)-3\{2-[1-(1carboxy-ethylamino)ethoxymethoxymethyl]-3,4,5-trihydroxy-tetrahydropyran-3yloxy\}-chromenylium.

The most widely used method for detecting latent fingerprints on porous surfaces relied on detecting amino acids that were present in natural peel secretions. Amino acids would be bonded tightly to cellulose (moisture levels were not excessive), thus maintaining the impression of a friction pattern on the ridge of the fingerprint [32]. The results of developing latent fingerprints used dragon fruit peel powder on the surface of HVS paper are shown in Figure 7, while the surface of the paperboard is shown in Figure 8, and the surface of the spectra paper is shown in Figure 9. 


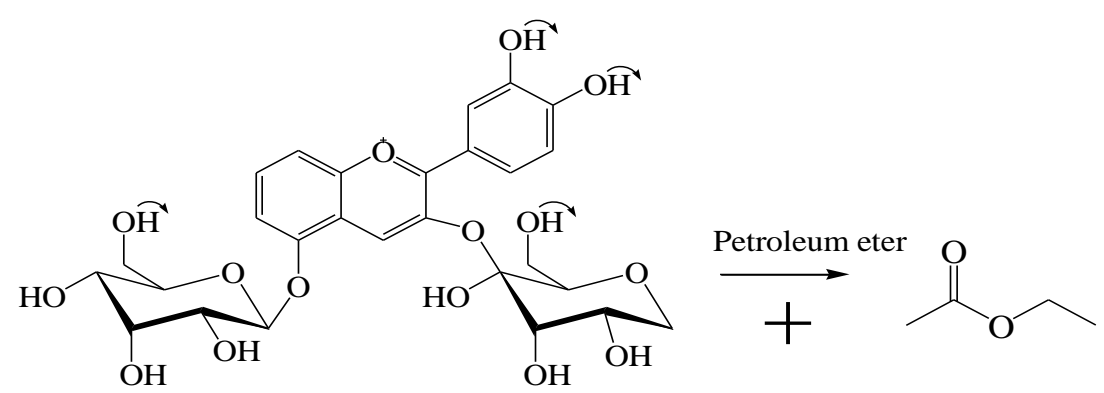

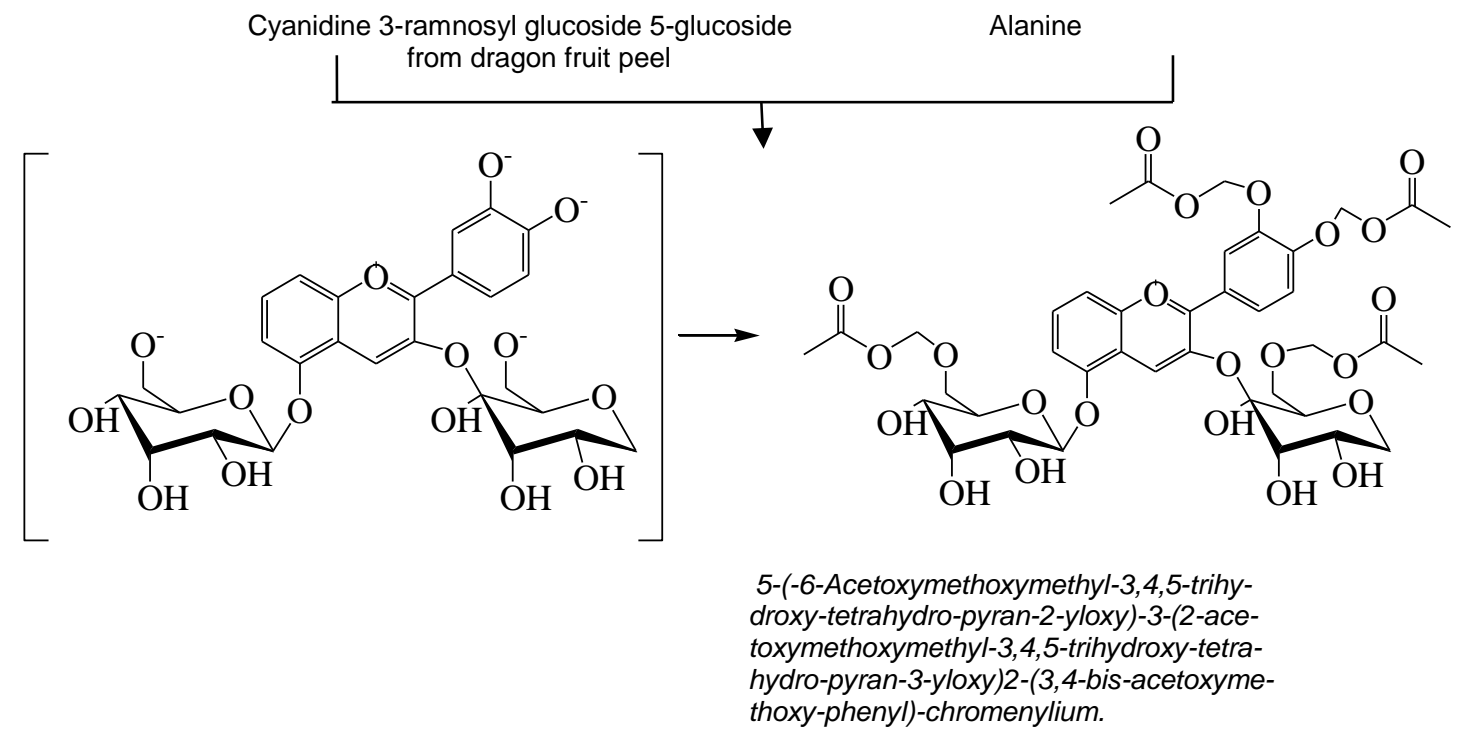

Figure 5. The reaction between cyanidine 3-ramnosyl glucoside 5-glucoside from dragon fruit peel with ethyl acetate

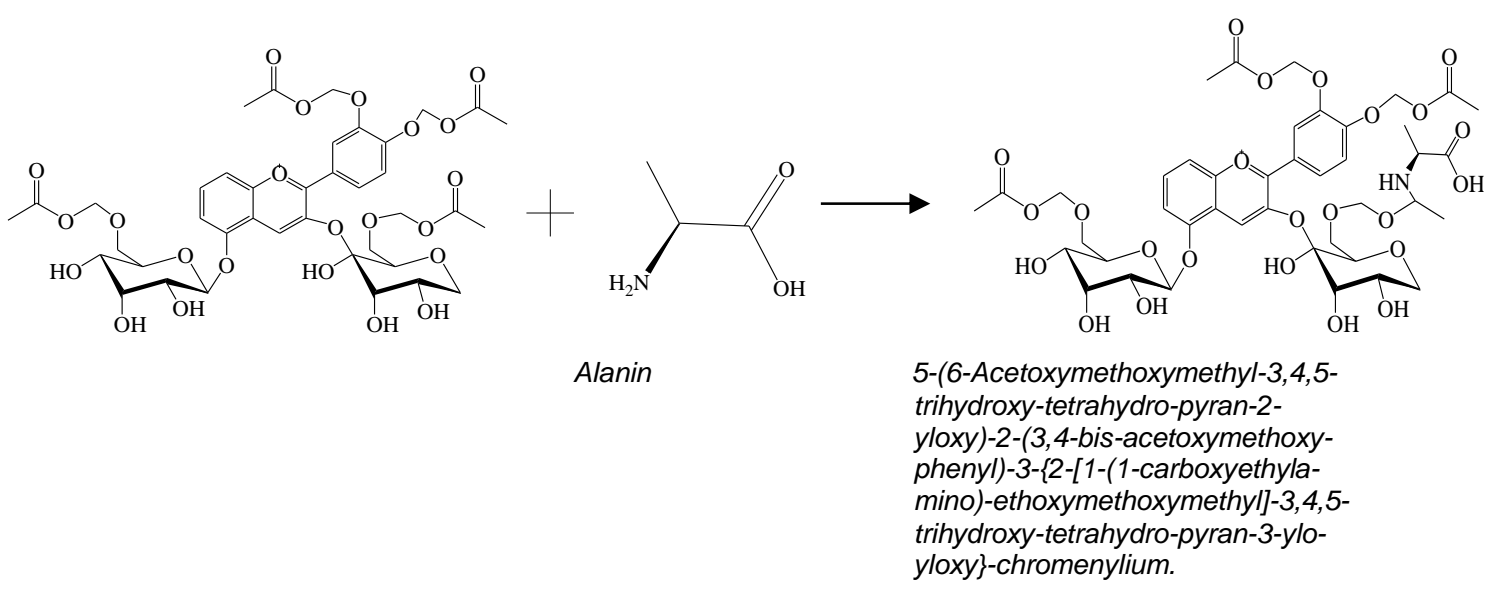

Figure 6. Intermediate reaction 5-(-6-Acetoxymethoxymethyl-3,4,5-trihydroxy-tetrahydro-pyran2-yloxy)-3-(2-acetoxymethoxymethyl-3,4,5-trihydroxy-tetrahydro-pyran-3-yloxy)2-(3,4bis-acetoxymetho-xy-phenyl)-chromenylium with alanine. 


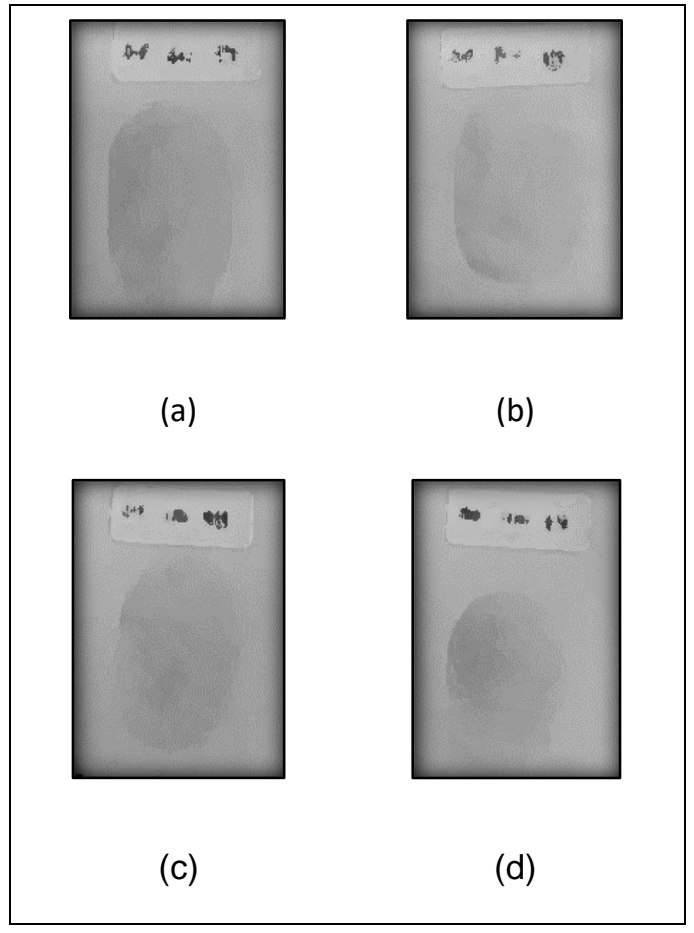

Figure 7. Development of latent fingerprints on the surface of HVS paper with powder/mesh sizes (a) 60, (b) 80, (c) 100 , and (d) 200

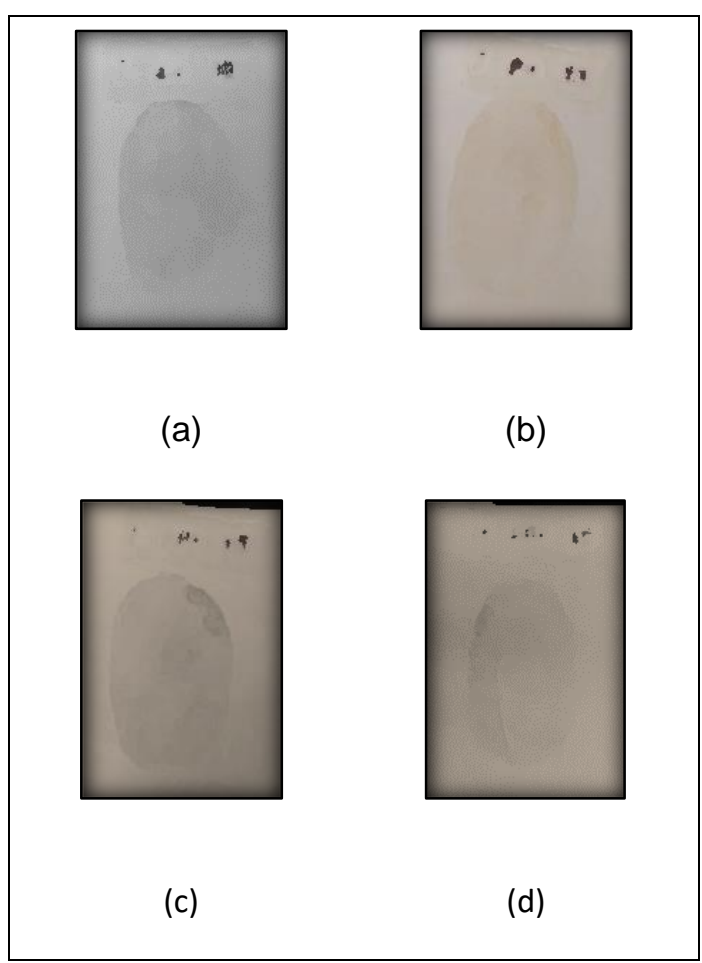

Figure 8. Development of latent fingerprints on the surface of paperboard with powder/mesh sizes (a) 60, (b) 80, (c) 100 , and (d) 200

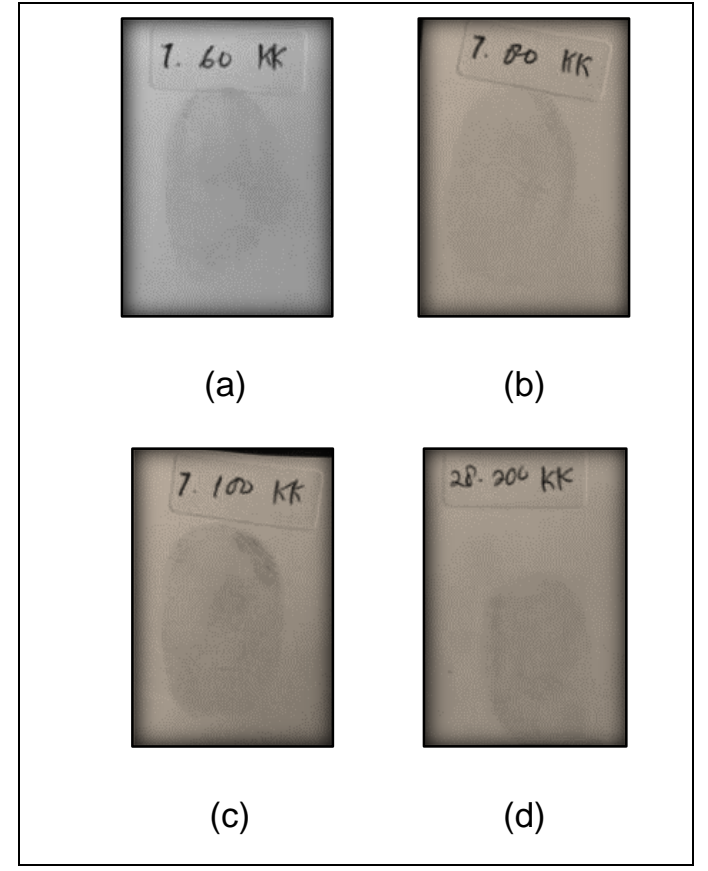

Figure 9. Development of latent fingerprints on the surface of the spectra paper with a powder size of (a) 60 mesh; (b) 80 mesh; (c) 100 mesh; (d) 200 mesh

The development of fingerprints on the surface of HVS paper, spectra paper, and paperboard was successfully developed with dragon fruit peel powder. Still, the fingerprint patterns that appeared on the surface of the paper were not visible. The fingerprint contrast was brown. Further heating of the paper can cause loss of contrast in fingerprints, as the background of the paper turns dark brown as a result of heating [33].

Based on the results, it was clear that the moulds developed depend on several factors. The quality of the printout is affected by the surface of the object that is touched, the condition of the skin when it rubs against the object, and the amount and type of residue on the skin [34]. The fingerprint pattern developed on the paper surface was influenced by the quality of the latent print left by the donor/fingerprint sample. As part of the paper there was no brown discolouration on 
the fingerprints left by the sample, due to the absence of a chemical reaction between the paper and fingerprints [35].

\section{Comparison of Fingerprint Patterns Based on Tribe, Blood Type and Gender}

This research was conducted using 90 fingerprint samples divided by ethnicity (30 Batak, 30 Javanese, and 30 Malay), blood type, and gender. Fingerprints could be widely used to identify a person in terms of the biology of their inheritance and differences between ethnic groups.

Ethnic diversity could be clearly identified phenotypes such as peel color, hair type, and the language used. Dermatoglyphics were another characteristic that could be used to identify ethnic groups. Indonesia has approximately 500 ethnic groups [19]. The percentage of fingerprint patterns formed based on terms is shown in Figure 10.

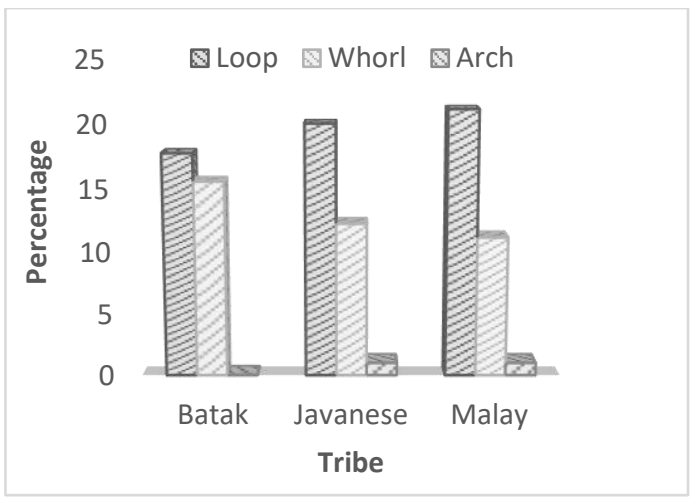

Figure 10. Fingerprints based on Tribe

Figure 10 shows that of the 90 fingerprint samples have the highest percentage in the loop pattern, namely $21.1 \%$ for the Malay ethnic group, $20 \%$ for the Batak ethnic group, and $17.7 \%$ for the Malay ethnic group. This shows that the loop fingerprint pattern was more dominant than other fingerprint patterns.

Another thing that is shown in the picture above was that the Malays have three pattern variations (Loop, Whorl, and Arch), in contrast to the Batak and Javanese tribes which only have two pattern variations (Loop and Whorl). The highest pattern percentage of the loop pattern. It was often found in the loop pattern in Javanese, then the whorl pattern [9]. Variation of student fingerprint patterns at Widya Mandala Madiun Catholic University. The variation in fingerprint patterns was represented by the variation in the percentage of each pattern (loop, whorl and arch) in the eight ethnic groups found. The Javanese, Dayak, Chinese, Flores, and Timorese have the largest percentage of loop patterns, the second is the whorl pattern, and the arch pattern ranks the smallest [18].

Loop type with a large percentage because the spread of loop fingerprint types was indeed more than other fingerprints. Several genes play a role in the formation of fingerprints, so the patterns undergo many variations. The fingerprint pattern is determined very strongly by genetic factors, but the period of formation was influenced by the environment [19].

Figure 11 shows that of the 90 samples had the highest percentage of loop fingerprint patterns, namely $31.1 \%$ for blood group $O$, $12.2 \%$ for group $B, 8.8 \%$ for $A B$ blood group, and $6.6 \%$ for group $A$. Another shows that blood groups $B$ and $O$ have three variations of the fingerprint pattern (Loop, Whorl, and Arch) different from blood groups $A$ and $A B$ which have two variations of the fingerprint pattern (Loop and Whorl). 


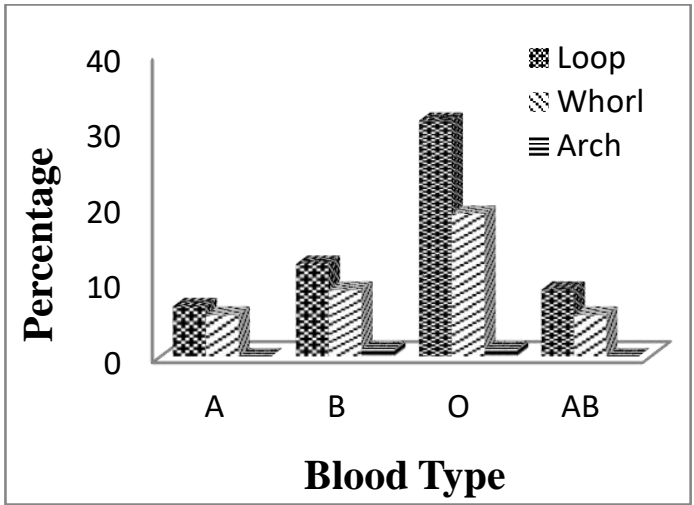

Figure 11. Fingerprints based on Blood Type

It is in accordance with the study of fingerprint patterns and their relation to blood groups that the loop pattern was dominant in all blood groups. The highest frequency of loop patterns was seen in blood group $\mathrm{O}$, followed by blood group B. The blood group of the majority of subjects in this study was blood type $\mathrm{O}$, followed by blood groups $\mathrm{B}, \mathrm{A}$, and $A B$. [21].

There was a relationship between the distribution of fingerprint patterns and blood groups. The distribution of fingerprint patterns in blood groups $A, B, A B$, and $O$ individuals is the highest frequency of loop, whorl, and then arch patterns [36]. The percentages of loop and whorl patterns were higher in blood group $\mathrm{O}$, followed by $\mathrm{B}, \mathrm{A}$, and $\mathrm{AB}$. In blood group $B$, there was a relationship with an arch pattern [25].

However, based on gender, the results of fingerprint patterns are shown in Figure 12. It has been found that in 90 samples, the most fingerprint patterns were based on gender, namely the loop pattern in the female gender $45.5 \%$. Another thing that is shown was that the female gender has three variations of the fingerprint pattern (Loop, Whorl, and Arch), which were different from the male gender those who have two variations of the fingerprint pattern (Loop and Whorl).

This was in line with the distribution of the most fingerprint patterns based on gender, namely loop, whorl, and the least arch pattern.

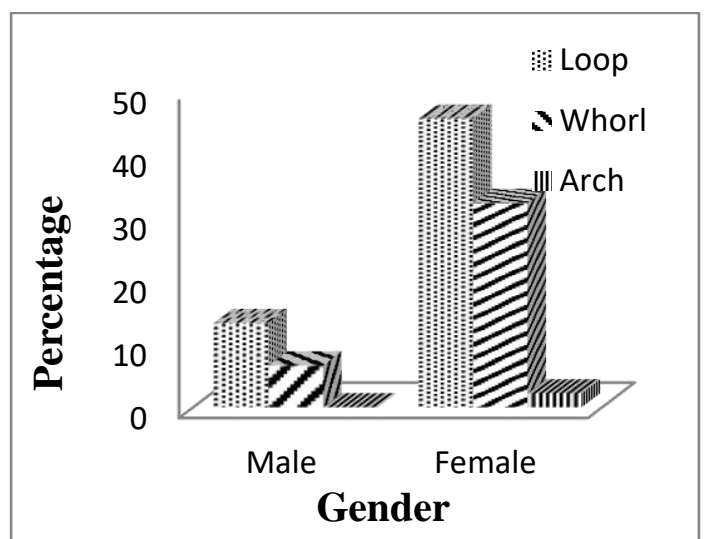

Figure 12. Fingerprints based on Gender

The loop pattern was more dominant in women. The distribution of the whorl pattern was almost equal in the two sexes [37]. The relationship between fingerprint patterns and blood groups in students stated that the dominant pattern in males and females was a loop, then whorl, and the smallest arch [38]. This was not following the study which stated there was no significant relationship between gender and fingerprint pattern [38].

\section{CONCLUSION}

Based on the results of this study, it can be concluded that the development of latent fingerprints was successfully carried out using dragon fruit peel powder. Visualization of dragon fruit peel powder was brown. The best visualization of latent fingerprints with powder sizes was found of 100 and 200 mesh. The best surface used was aluminium foil and glass preparations. Meanwhile, fingerprints on the paper surface 
result in poor visualization; it might due to the ridge was not visible. However, the most dominant fingerprint patterns based on ethnicity, blood group, and gender were loop patterns, whorl, and the least arch. The ways of the loop were found to be Malay, Batak, and Javanese with the percentage of 21.1; 20.0; and 17.7 percents, respectively. The percentage of loop patterns based on blood group was found to be $O=31.1 ; B=12.2$; $A B=8.8$; and $A=6.6$ percent. Besides that, the loop fingerprint patterns based on gender were found to be 45.5 in women and 13.3 percents in men.

\section{REFERENCES}

[1] S. Upadhayay \& B. Yadav, "Latent Fingerprint on Human Peel: A Silent Diagnosis," Journal of Forensic Science \& Criminology, vol. 4, no. 2, pp. $1-4,2019$

[2] P. Kiran \& D. Sridevi, "Study on Efficiency of Alternate Light Source For Detection Of Latent Fingerprints," Journal Forensic Sci \& Criminal Inves, vol. 9, no. 5, pp. 001-003, 2018

DO:10.19080/JFSCI.2018.09.555774

[3] C. Elishian \& R. Ketrin, "Pengembangan Material Serbuk Silika Untuk Identifikasi Sidik Jari," Jurnal IImu Forensik, vol.10, no. $1, \quad$ pp. 1-7, 2011. DOI: 10.14203/jkti.v13i1.126

[4] S. M. Singh \& K, Rajeev, "Crime Investigating Technique To Development Of Invisible Fingerprints On Surfaces Using Rock Phosphate Powder," International Journal of Forensic Sciences, vol. 2, no. 3, pp. 1-5, 2018. DOI:10.2139/ssrn.3428918

[5] M. Y. Omar \& L. Ellsworth, "Possibility Of Using Fingerprint Powder For Development of Old Fingerprints." Sains Malaysiana, 41(4):499-504, 2012

[6] M. Sekar \& N. F. Zulkifli, "Development Of Natural Latent Fingerprint Powder
From Durian Seeds-A Green And Effective Approach In Crime Scene." Indo American Journal of Pharmaceutical Sciences, vol. 4, no. 8, pp. 2362-2367, 2017.

DOI: 10.5281/zenodo.845385

[7] R. K. Garg, H. Kumari, \& R. Kaur, "A New Technique For Visualisasi Of Latent Fingerprints On Various Surfaces Using Powder From Turmeric: A Rhizomatous Herbaceous Plant (Curcuma longa)." Egyptian Journal of Forensic Science, vol. 1, pp. 53-57, 2011.

DOI:10.1016/J.EJFS.2011.04.011

[8] S. A. Sari, Jasmidi, A. Kembaren, \& A. N. IImi, "Development Of Eco- Friendly Visualization Using Herb." Asian Journal Of Chemistry, vol. 31, no. 11, pp. 2601-2606, 2019

DOI:10.14233/ajchem.2019.22218

[9] S .A. Sari, H. Ningsih, Jasmidi, A. Kembaren, \& N. A. Mahat, "Development Of Gambir Powder As A Cheap And Green FingerprintPowder For Forensic Applications." AIP Conference Proceedings, 2155(1): 020023-1-020023-5, 2019.

DOI :https://doi.org/10.1063/1.5125527

[10] S. A. Sari, Y. Sinaga, Jasmidi, Mahmud, \& T. Juwitaningsih, "A New Latent Fingerprint Method using Natural Powder Purple Sweet Potato (Ipomoea batatas L.Poiret)," Proceeding. The Eight National Symposium and The Fourth International Symposium Bangkok Thonburi University, pp. 329343, April, 26 2020.

[11] H. C. Henry \& R. E. Gaensslen, Advances In Fingerprint Technology Second Edition, Washington DC: CRC Press, 2006 ISBN:9780849309236

[12] A. Sulistiami, W. Waeniati, \& I. N. Suwastikaet "Pertumbuhan Organ Tanaman Buah Naga (Hylocereus polyrhizus) Pada Medium Ms Dengan Penambahan Bap Dan Sukrosa," Jurnal Natural Science, vol. 1, no. 1, pp. 27-33, 2012.

DOI:10.22487/25411969.2012.v1.i1.1016 
[13] I. Chastanti. "Variasi Dermatoglifi Mahasiswa dari Perkawinan Berbeda Suku di FKIP Universitas Labuhanbatu," Jurnal Penelitian dan Pembelajaran MIPA, vol. 5, no. 2, pp. 87-90, 2020. DOI: 10.31604/eksakta.v5i2.87-90

[14] E. R. Amaliyah, "Pengaruh Perbandingan Proposi Bubuk Kulit Buah Naga (Hylocereus polyrhizus) Dengan Mordan Tunjung ( $\mathrm{Fe}\left(\mathrm{SO}_{4}\right)$ Terhadap Hasil Pewarnaan Alami Rambu," e-journal, vol. 7, no. 1, pp. 6269, 2018

[15] M. Ali, "Optimasi Pengolahan Teh Kulit Buah Naga (Hylocereus polyrhizus)," AGRITEPA, vol. 2, no. 1, pp. 216-226, 2016.

DOI: 10.37676/agritepa.v3i1.305

[16] R. Wahyuni, "Pemanfaatan Kulit Buah Naga Super Merah (Hylicereus costaricensis) Sebagai Sumber Antioksidan Dan Pewarna Alami Pada Pembuatan Jelly," Jurnal Teknologi Pangan, vol. 2, no. 1, pp. 68-85, 2011. DOI:10.35891/tp.v2i1.482

[17] W.Enjelina, Y. O. Rilza, \& Z. Erda, “. Pemanfaatan kulit buah naga merah (Hylocereus polyrhizus sp.) untuk memperpanjang umur simpan mie basah". AcTion: Aceh Nutrition Journal, vol.4, no.1, pp. 63-69,2019. DOI :10.30867/action.v4i1.162

[18] P. A. Handayani \& A. Rahmawati, "Pemanfaatan Kulit Buah Naga (Dragon fruit) Sebagai Pewarna Alami Makanan Pengganti Pewarna Sintetis," Jurnal Bahan Alam Terbarukan, vol.1, no. 2, pp. 19-24, 2012.

DOI: 10.15294/jbat.v1i2.2545

[19] K. Purbasari \& A. R. Sumadji, "Variasi Pola Sidik Jari Mahasiswa Berbagai Suku Bangsa Di Universitas Kotalik Widya Mandala Madium," Florea: Jurnal Biologi \& Pembelajarannya. vol. 4, no. 2, pp. 47-54, 2017 .. DOI: $10.25273 /$ florea.v4i2.1813

[20] A. A. Mehta \& A. A. Mehta, "Palmar Dermatoglyphis In ABO, $\mathrm{RH}$ Blood Group." Internasional Journal Of Biological dan Medical Research, vol. 2, no. 4, pp. 961-964, 2011.

DOI: 10.1 .1 .302 .7453
[21] C. S. Vadde, P. A. Kumar, \& P. Ramakhrisna., "A Study Of Pattern Of Fingerprints In Relation To Blood Groups," East African Scholars Journal Of Medical Sciences, vol. 3, no. 2, pp. 37-40, 2020.

DOI: 10.36349/EASMS.2020.v03i02.002

[22] E. Husni, N. Suharti, \& A. P. T. Atma, "Karakteristik Simplisia dan Ekstrak Daun Pacar Kuku (Lawsonia inermis Linn) serta Penentuan Kadar Fenolat Total dan Uji Aktivitas Antioksidan," Jurnal Sains Farmasi \& Klinis, vol. 5, no.1, pp. 12-16, 2018.

DOI: $10.25077 / j s f k .5 .1 .12-16.2018$

[23] R. P. Downham, S. Mehmet, V.G. Sears, "A Pseudo-Operational Investigation Into The Development Of Latent Fingerprints On Flexible Plastic Packaging Films," Journal Of Forensic Identification, vol. 62, no.6, pp. 661682, 2012

[24] P. Thomas \& K. Farrugia, "An Investigation Into The Enhancement Of Fingermarks In Blood On Paper With Genipin And Lawsone," Science and Justice, vol.53, pp. 315-320, 2013. https://doi.org/10.1016/j.scijus.2013.04 .006

[25] R. Rosa, P. Veronesi, \& C. Leonelli, "Microwave Selective Thermal Development Of Latent Fingerprints On Porous Surfaces: Potentialities Of The Method And Preliminary Experimental Results," J Forensic Sci, vol. 58, no. 5, pp. 1314-1321, 2013.

https://doi.org/10.1111/1556-4029.12238

[26] R. S. Harjanti, "Optimasi Pengambilan Antosianin dari Kulit Buah Naga Merah (Hylocereus polyrhizus) Sebagai Pewarna Alami pada Makanan," Chemica, vol. 3, no. 2, pp. 39-45, 2016. DOI: 10.26555/chemica.v3i2.5922

[27] M. Priska, N. Peni, L. Carvallo, \& Y. D. Ngapa, "Review: Antosianin dan Pemanfaatannya," Cakra Kimia (Indonesia E-Journal of Applied Chemistry), vol. 6, no. 2, pp. 79-97, 2018.

[28] P. Sari, F. Agustina, M. Komar, M. Fauzi, \& T. Lindriati, "Ekstraksi Dan Stabilitas Antosianin Dari Kulit Buah 
Duwet (Syzgium cumini)," Jurnal Teknol dan Industri Pangan, vol. XVI, no. 2, pp. 142-150, 2005.

[29] N. P. Noviantari, L. Suhendra, \& N. M. Wartini, "Pengaruh Ukuran Partikel Bubuk dan Konsentrasi Pelarut Aseton Terhadap Karakteristik Ekstrak Warna Sargassum polycystum," Jurnal Rekayasa Dan Manajemen Agroindustri, vol. 5, no. 3, pp. 102-112, 2017.

[30] A. Yuserlina, "Peranan Sidik Jari Dalam Proses Penyidikan Untuk Menentukan Pelaku Tindak Pidana," Jurnal Cendekia Hukum, vol. 3, no. 1, pp. 4660, 2017.

http://doi.org/10.33760/jch.v3i1.10

[31] R. Jelly, S. W. Lewis, C. Lennard, K.F. Lim, \& J. Alomog, "Substituted Naphthoquinones As Novel Amino Acid Sensitive Reagent For The Detection Of Latent Fingermark On Paper Surface," Talanta, vol. 82, no. 5, pp. 1717-1724, 2010.

DOI: 10.1016/j.talanta.2010.07.064

[32] R. Jellya, E. L. T. Pattona, C. Lennardb, S. W. Lewis, \& K. F. Lim, "The Detection Of Latent Fingerprint On Porous Surfaces Using Amino Acid Sensitive Reagen: A Review," Analytica Chimica Acta, vol. 652, pp. 128-142, 2009.

DOI: 10.1016/j.aca.2009.06.023

[33] T. C. Johnson, A.S. Brown, U. Okafor, \& Y. J. Lee, "Development Of Reverse Fingerprint Lifting Techniques For Forensic Applications," J Forensic Investigation, vol. 8, no. 1, pp. 1-8, 2020.

DOI: 10.13188/2330-0396.1000046
[34] A. G. Brown, D. Sommerville, B. J. Reedy, R. G. Shimmon, \& M. Tahtouh, "Revisiting The Thermal Development Of Latent Fingerprint On Porous Surfaces: New Aspects And Refinements," J Forensic Sci, vol. 54, no. 1 pp. 114-121, 2009. DOI:10.1111/j.1556-4029.2008.00902.x

[35] A. Bharawadja, P. K. Saraswat, S. K. Aggarwal, P. Banerji, \& S. Bharadwaja, "Pattern of Fingerprint in Different $A B O$ Blood Groups," JIARM, vol. 26, no.1, pp. 6-9, 2004.

[36] T.C. Omuruka, C. W. Paul, \& J. N. Paul, "Relationship Between Fingerprint Patterns and Gender Among Port Harcourt Residents, Rivers State, Nigeria," Internasional Journal of Pharma Research and Health Sciences, vol. 5, no. 6, pp. 1935-1938, 2017.

DOI: 10.21276/ijprhs.2017.06.07

[37] P. N. Kamaradgi, R.M Marigoudar, V. B. Jatti, \& A. Kumar, "A Correlation Study Of Patterns Of Fingerprint With Blood Groups Among The Students Of S.S.S.M.S \& R.C., Davangere," Indian Journal of Forensic Medicine \& Toxicology, vol. 13 , no. 2 , pp. 120-124, 2019.

https://doi.org/10.37506/ijfmt.v13i2.2304

[38] P. Thakur, \& R. K. Garg, "Fingerprint Patternt in Relation to Gender and Blood Group among Residents of Central Indian District," Indian Journal of Forensic Medicine \& Toxicology, vol. 13, no. 3, pp. 73-77, 2019 https://doi.org/10.37506/ijfmt.v13i3.270 